\title{
Bevacizumab: a new hope?
}

\section{Eye (2009) 23, 1755-1757; doi:10.1038/sj.eye.6702937}

The introduction of vascular endothelial growth factor (VEGF) antibodies has markedly improved the visual prognosis for patients with neovascular age-related macular degeneration (AMD). Patients presenting with good vision, can now look forward to near normal quality of life, with sufficient vision to drive and read. The results of anti-VEGF therapy stand in sharp contrast to those of argon laser treatment or photodynamic therapy. ${ }^{1-6}$

Pegaptanib sodium (macugen; a pegylated oligonucleotide modified to bind $\mathrm{VEGF}_{165}$ ) was the first intravitreal treatment. The VISION trials, of pegaptanib on neovascular AMD, found $70 \%$ of treated eyes had stable vision, compared to $55 \%$ in the sham group. ${ }^{1}$ Late in 2006, the ANCHOR and MARINA trials, demonstrated the efficacy of ranibizumab (a monoclonal antibody fragment binding VEGF-A) for neovascular AMD., ${ }^{2,3}$ These reported visual stabilisation in $94-96 \%$ and improvement in vision in $40 \%$ of eyes. Both pegaptanib and ranibizumab have a European licence for neovascular AMD and the National Institute for Health and Clinical Excellence (NICE) have considering their use in the NHS, in the meantime, some primary care trusts are already funding ranibizumab or pegaptanib treatment. This is good news for the 25000 patients, who develop neovascular AMD in the United Kingdom each year.

However, before licensing of ranibizumab, ophthalmologists started to use bevacizumab (Avastin), a full-length anti-VEGF antibody, licenced for colorectal carcinoma treatment. Dr Rosenfeld first used this drug as an intravenous infusion, finding similar results to intravitreal ranibizumab. ${ }^{7}$ He subsequently gave it intravitreally, again with positive results. ${ }^{8}$ Within 12 months, bevacizumab use had become international and several reports on its efficacy and safety were published. ${ }^{9-13}$

In this edition of EYE, Cleary et $\mathrm{al}^{14}$ contribute to the literature, reporting on the effect of intravitreal bevacizumab on occult and classic

KC Madhusudhana and RSB Newsom

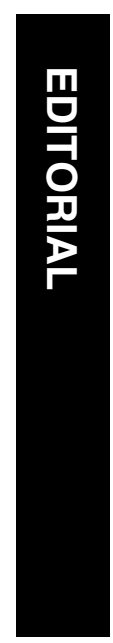

$\mathrm{CNV}$ in 112 eyes. Overall vision improved from 0.84 Log MAR (6/41) at baseline to 0.69 Log MAR $(6 / 30)$ at 9 months after an average of 1.69 injections. There was a reduction in macular thickness and some adverse events such as retinal pigment epithelial rip, submacular haemorrhage, and endophthalmitis. These results are similar to others published about intravitreal bevacizumab. Avery et $a l^{11}$ reported a series of 79 patients, finding a reduction in macular thickness in 55\% at 1 week, with an improvement in vision from 20/200 to 20/125 at 1 month. Similarly, Rich et $a l^{10}$ observed improvements in visual acuity and macular thickness at 1 week. At 3 months, the visual acuity improved from $20 / 160$ to $20 / 125$ and the mean central retinal thickness decreased by 99.6 microns after an average 2.3 injections of intravitreal bevacizumab.

At the 2007 Association for Research in Vision and Ophthalmology (ARVO) meeting, the interest in bevacizumab was intense with 154 presentations. Key papers again came from Dr Rosenfeld's group. They presented data from a group of 403 patients treated with bevacizumab; ${ }^{15}$ of these, eight (1.9\%) did not achieve a fluid-free macula. These eight were treated with ranibizumab; five had improved optical coherence tomogram (OCT) measurement, but only three $(0.74 \%)$ had an improvement in vision. Another paper looking at patients switched from bevacizumab therapy to ranibizumab therapy, found a 2-3 letter improvement of vision $(P>0.05) .{ }^{16}$ This may, however, be due to an ongoing improvement in macular function (personal communication). Others found significantly better results with bevacizumab and ranibizumab when compared to pegaptanib sodium. ${ }^{17}$ For some bevacizumab has become a 'generic ranibizumab' ${ }^{18}$ but to fully assess the difference between the two drugs, the US and UK governments have set up head-to-head trials to determine the safety and effectiveness of these treatments.

As with many new treatments, there are several unresolved issues over the use of intravitreal anti-VEGF therapy. Monthly
Southampton Eye Unit, Southampton, UK

Correspondence: RSB Newsom, Southampton Eye Unit, Tremona Road, Southampton SO16 6YD, UK

Tel: +44 0238079 4758; Fax: +440238079 4120 E-mail: Richard.Newsom@ suht.swest.nhs.uk

Support: none Financial interests: none 
ranibizumab injections may cost up to $0.5 \%$ of the total NHS budget ( $£ 500$ million). There are several trials looking at reducing the dosage frequency (to save cost and reduce complications), however results from the PIER trial, found that the initial improvement in vision was not sustained, with vision returning to baseline at 1 year. ${ }^{18,19}$ More positive data have come from the PrONTO study (40 patients), which suggests that OCT-guided treatment of patients can improve the visual prognosis while avoiding monthly ranibizumab injections. ${ }^{20}$ The dosage $(0.3$ or $0.5 \mathrm{mg}$ ) and frequency of ranibizumab are still an issue. There is some evidence that $0.5 \mathrm{mg}$ is more effective than $0.3 \mathrm{mg}^{2,3}$ but the SAILOR (a safety) trial suggests it may also cause more stroke than the $0.3 \mathrm{mg}$ dose $(1.2$ vs $0.3 \% ; P=0.02) .{ }^{21}$ The total stroke rate is however lower than expected for that population making this data difficult to interpret.

Bevacizumab, a larger molecule, is given less frequently than ranibizumab, reducing the potential of systemic side effects and the risk of endophthalmitis. ${ }^{22}$ As such, some countries currently support the use of only bevacizumab, excluding ranibizumab on cost grounds.

In summary, anti-VEGF treatment has revolutionised the management of neovascular AMD, worldwide. Stabilisation or improvement in vision is achieved for the majority of patients treated with either bevacizumab or ranibizumab. Identification and appropriate referral of patients, before irreversible loss of vision occurs is now a clear priority. Research is being focused on the head-tohead clinical trials of bevacizumab and ranibizumab and developing treatments for the underlying dry AMD, which now determines the visual prognosis for the majority of our patients with macular degeneration.

\section{References}

1 Gragoudas ES, Adamis AP, Cunningham Jr ET, Feinsod M, Guyer DR, VEGF Inhibition Study in Ocular

Neovascularization Clinical Trial Group. Pegaptanib for neovascular age-related macular degeneration. $N$ Engl J Med 2004; 351: 2805-2816.

2 Brown DM, Kaiser PK, Michels M, Soubrane G, Heier JS, Kim RY, et al., ANCHOR Study Group. Ranibizumab versus verteporfin for neovascular age-related macular degeneration. N Engl J Med 2006; 355: 1432-1444.

3 Rosenfeld PJ, Brown DM, Heier JS, Boyer DS, Kaiser PK, Chung CY, et al., MARINA Study Group. Ranibizumab for neovascular age-related macular degeneration. $N$ Engl J Med 2006; 355: 1419-1431.

4 Macular Photocoagulation Study Group. Persistent and recurrent neovascularization after laser photocoagulation for subfoveal choroidal neovascularization of age-related macular degeneration. Arch Ophthalmol 1994; 112: 489-499.

5 Treatment of Age-related Macular Degeneration with Photodynamic Therapy (TAP) Study Group. Photodynamic therapy of subfoveal choroidal neovascularisation in agerelated macular degeneration with verteporfin: one-year results of 2 randomized clinical trials - TAP report 1. Arch Ophthalmol 1999; 117: 1329-1345.

6 Verteporfin in Photodynamic Therapy Study Group. Verteporfin therapy of subfoveal choroidal neovascularisation in age-related macular degeneration: two-year results of a randomized clinical trial including lesions with occult with no classic choroidal neovascularisation-verteporfin in photodynamic therapy report 2. Am J Ophthalmol 2001; 131: 541-560.

7 Michels S, Rosenfeld PJ, Puliafito CA, Marcus EN, Venkatraman AS. Systemic bevacizumab (Avastin) therapy for neovascular age-related macular degeneration twelveweek results of an uncontrolled open-label clinical study. Ophthalmology 2005; 112: 1035-1047.

8 Rosenfeld PJ, Moshfeghi AA, Puliafito CA. Optical coherence tomography findings after an intravitreal injection of bevacizumab (avastin) for neovascular age-related macular degeneration. Ophthalmic Surg Lasers Imaging 2005; 36: 331-335.

9 Spaide RF, Laud K, Fine HF, Klancnik Jr JM, Meyerle CB, Yannuzzi LA et al. Intravitreal bevacizumab treatment of choroidal neovascularization secondary to age-related macular degeneration. Retina 2006; 26: 383-390.

10 Rich RM, Rosenfeld PJ, Puliafito CA, Dubovy SR, Davis JL, Flynn Jr HW et al. Short-term safety and efficacy of intravitreal bevacizumab (Avastin) for neovascular agerelated macular degeneration. Retina 2006; 26: 495-511.

11 Avery RL, Pieramici DJ, Rabena MD, Castellarin AA, Nasir MA, Giust MJ. Intravitreal bevacizumab (Avastin) for neovascular age-related macular degeneration. Ophthalmology 2006; 113: 363-372.

12 Ladewig MS, Ziemssen F, Jaissle G, Helb HM, Scholl HP, Eter $\mathrm{N}$ et al. Intravitreal bevacizumab for neovascular age-related macular degeneration. Ophthalmologe 2006; 103: 463-470 (in German).

13 Bashshur ZF, Bazarbachi A, Schakal A, Haddad ZA, El Haibi CP, Noureddin BN. Intravitreal bevacizumab for the management of choroidal neovascularization in age-related macular degeneration. Am J Ophthalmol 2006; 142: $1-9$.

14 Cleary CA, Jungkim S, Ravikumar K, Kelliher C, Acheson RW, Hickey-Dwyer M. Intravitreal bevacizumab in the treatment of neovascular age related macular degeneration, 6 and 9 month results. Eye 2007 (in press).

15 Stepien KE, Rosenfeld PJ, Puliafito CA, Dubovy SR, Davis $\mathrm{JL}$, Berrocal AM et al. Sequential comparison of avastin (bevacizumab) followed by lucentis (ranibizumab) in the treatment of neovascular age related macular degeneration. abstract (4534/B215), Association for Research in Vision and Ophthalmology Annual Meeting, Fort Lauderdale, USA, 6-10 May 2007.

16 Nguyen JK, Heier JS, Cleary TS, Morley MG, Frederick Jr AR, Topping TM et al. Ranibizumab treatment of patients with neovascular AMD previously treated with intravitreal bevacizumab. abstract (3368/B515). Association for Research in Vision and Ophthalmology Annual Meeting, Fort Lauderdale, USA, 6-10 May 2007.

17 Sund NJ, Lai MM, Capone Jr A, Hassan TS. Efficacy of intravitreal bevacizumab (Avastin ${ }^{\mathrm{TM}}$ ) vs ranibizumab (lucentis $^{\mathrm{TM}}$ ) as first line monotherapy for the treatment of neovascular age-related macular degeneration. Abstract (1813/B673). Association for Research in Vision and Ophthalmology Annual Meeting, Fort Lauderdale, USA, 6-10 May 2007. 
18 la Cour M. Intravitreal VEGF-inhibitors: is Avastin a generic substitute for Lucentis? Acta Ophthalmol Scand 2007; 85: 2-4.

19 Brown DM, Yue H, Shams N. Ranibizumab (lucentis) in neovascular age-related macular degeneration (AMD): subgroup analysis of year 1 PIER efficacy data. Abstract (4540/B221). Association for Research in Vision and Ophthalmology Annual Meeting, Fort Lauderdale, USA, 6-10 May 2007.

20 Fung AE, Lalwani GA, Rosenfeld PJ, Dubovy SR, Michels S, Feuer WJ et al. An optical coherence tomography-guided, variable dosing regimen with intravitreal ranibizumab (Lucentis) for neovascular age-related macular degeneration. Am J Ophthalmol 2007; 143: 566-583.

21 http://www.medpagetoday.com/Ophthalmology/ GeneralOphthalmology/tb/4949, accessed on 18 May 2007. 22 Fung AE, Rosenfeld PJ, Reichel E. The International Intravitreal Bevacizumab Safety Survey: using the internet to assess drug safety worldwide. Br J Ophthalmol 2006; 90: 1344-1349. 